\title{
SARCOPENIA PREVALENCE AND ASSOCIATED FACTORS IN ELDERLY PEOPLE ASSISTED BY PRIMARY HEALTH CARE, SÃO PAULO, BRAZIL: A CROSS-SECTIONAL STUDY
}

\author{
SARCOPENIA PREVALENCE IN ELDERLY
}

\author{
L. Campos Aparecido Martins ${ }^{1}$, P.J. Fortes Villas Bôas ${ }^{1}$, K.C. Portero McLellan ${ }^{1,2}$
}

\begin{abstract}
Background: Sarcopenia is prevalent in the elderly population and has been postulated as the main factor for the decline in strength with age, representing a health deficient state with a personal high cost. Objective: To identify the prevalence of sarcopenia and its association with anthropometric and socioeconomic factors in elderly patients assisted by primary health care. Design and Methods: Cross-sectional study conducted with 136 individuals aged 60 years and older. Socioeconomic and demographic status, and anthropometric profile were assessed for all individuals. For the diagnosis of sarcopenia it was considered muscle wasting associated with loss of muscle strength. Logistic regression model was performed to identify the risk factors for sarcopenia considering a 5\% significance level for the corresponding p-value. Results: The prevalence of sarcopenia in the studied population was $37.5 \%$, however being higher among men $(66.6 \%)$. Of those individuals with sarcopenia, $50 \%$ of men and $29 \%$ of women were overweight, $35 \%$ of men and $64 \%$ of women had abnormal waist to hip ratio. Retirement (OR: 2.165; CI: 1.037 to 4.250 ) and smoking (OR: 9.435; CI: 1.228 to 72.499) represented risk factors for sarcopenia. Conclusion: The study population had a high prevalence of sarcopenia, along with a high prevalence of abdominal obesity, which may be an important causal factor for insulin resistance and type 2 diabetes susceptibility. Sarcopenia was associated with behavioral (smoking) and demographic (retirement) variables.
\end{abstract}

Key words: Sarcopenia, antropometry, elderly.

\section{Introduction}

The progressive and generalized loss of skeletal muscle mass and strength that occurs with aging is called sarcopenia (1). Sarcopenia is prevalent in the elderly population and it has been postulated as the main factor in the decline of strength with aging, poor health, high personal cost, functional impairment, disability, falls, loss of independence, decreased quality of life and death (2). It is associated with an increased probability of disability, socioeconomic costs and expenses on health care (3). Sarcopenia does not present a clinical widely accepted definition, and diagnostic criteria are not consensual (1). Sarcopenia had diagnostic criteria and classification defined by the European Society for Clinical Nutrition and Metabolism Special Interest Groups (ESPEN-SIG), International Working Group on Sarcopenia (IWGS), and

1. Public Health Graduate Program, Medical School, Sao Paulo State University, UNESP/Botucatu, SP, Brazil; 2. Texas Institute for Kidney and Endocrine Disorders, Lufkin, TX, USA

Corresponding Author: Katia Cristina Portero McLellan, 10 Medical Center Blvd, Ste A, Lufkin, TX 75904, USA, kaportero@gmail.com
European Working Group on Sarcopenia in Older People (EWGSOP) (4). The European Consensus recommended for diagnosing sarcopenia the presence of muscle loss and muscle function loss (strength and / or muscular performance), which is evaluated by grip strength (1).

Studies showed prevalence of sarcopenia ranging from $0 \%$ to $45.2 \%$ (5), 5 to $13 \%$ among elderly aged 60 and 70 years (6) and $11 \%$ to $50 \%$ among those aged 80 or more (1). When considering the muscle mass index (MMI), sarcopenia prevalence ranged from $22.6 \%$ to $51.9 \%$ (7), $12.8 \%$ with bioelectrical impedance (BIA) and $21.0 \%$ with dual energy X-ray absorptiometry (DEXA) (8).

As the aging process constitutes one of the contributing factors for the reduction of skeletal muscle mass and the elderly population is continuously increasing, it becomes important and necessary to study the factors associated with sarcopenia. Thus, this study aims to identify the prevalence of sarcopenia and its associated factors in the elderly population assisted by Primary Health Care. 
Table 1

Sociodemographic and behavioral characteristics of the individuals according to gender and sarcopenia status.

Brazil, $2013(\mathrm{n}=136)$

\begin{tabular}{|c|c|c|c|c|c|c|c|}
\hline & \multirow[b]{2}{*}{ All (136) } & \multicolumn{3}{|c|}{ Men (n=30) } & \multicolumn{3}{|c|}{ Women $(n=106)$} \\
\hline & & $\begin{array}{c}\text { No Sarcopenia } \\
(\mathrm{n}=10)\end{array}$ & $\begin{array}{c}\text { Sarcopenia } \\
(\mathrm{n}=20)\end{array}$ & p-value* & $\begin{array}{c}\text { No Sarcopenia } \\
(\mathrm{n}=75)\end{array}$ & $\begin{array}{c}\text { Sarcopenia } \\
(n=31)\end{array}$ & p-value* \\
\hline \multicolumn{8}{|l|}{ Sociodemographic variables } \\
\hline Age & & $69.20 \pm 7.9$ & $73.35 \pm 7.6$ & & $68.59 \pm 5.9$ & $72.06 \pm 6.6$ & \\
\hline \multicolumn{8}{|l|}{ Education } \\
\hline Illiterate & 10 & - & $1(5.0)$ & & $5(6.7)$ & $4(12.9)$ & \\
\hline Fundamental Complete & 10 & - & $1(5.0)$ & 0.49 & $5(6.7)$ & $4(12.9)$ & 0.14 \\
\hline Fundamental Incomplete & 92 & $6(60.0)$ & $14(70.0)$ & & $50(66.7)$ & $22(70.9)$ & \\
\hline Completed High School & 18 & $4(40.0)$ & $3(15.0)$ & & $11(14.7)$ & - & \\
\hline Completed College & 6 & - & $1(5.0)$ & & $4(5.3)$ & $1(3.2)$ & \\
\hline \multicolumn{8}{|l|}{ Marital Status } \\
\hline Married/with a partner & 67 & $7(70.0)$ & $17(85.0)$ & 0.33 & $30(40.0)$ & $13(41.9)$ & 0.85 \\
\hline Alone (single, divorced, widow) & 69 & $3(30.0)$ & $3(15.0)$ & & $45(60.0)$ & $18(58.1)$ & \\
\hline \multicolumn{8}{|l|}{ Profession } \\
\hline Retired & 96 & $7(70.0)$ & $14(70.0)$ & 1.00 & $58(77.3)$ & $17(54.8)$ & $0.04^{*}$ \\
\hline Working & 13 & $3(30.0)$ & $6(30.0)$ & & $3(4.00)$ & $1(3.2)$ & \\
\hline Not working & 27 & & & & $14(18.7)$ & $13(41.9)$ & \\
\hline \multicolumn{8}{|l|}{ Socioeconomic level } \\
\hline $\mathrm{B}(10$ to $20 \mathrm{MW})$ & 2 & $1(10.0)$ & $1(5.0)$ & & - & - & \\
\hline $\mathrm{C}(4$ to $10 \mathrm{MW})$ & 10 & - & $3(15.0)$ & 0.55 & $5(6.7)$ & $2(6.7)$ & 0.96 \\
\hline $\mathrm{D}(2$ to $4 \mathrm{MW})$ & 83 & $7(70.0)$ & $11(55.0)$ & & $47(62.7)$ & $18(60.0)$ & \\
\hline $\mathrm{E}$ (up to $2 \mathrm{MW}$ ) & 40 & $2(20.0)$ & $5(25.0)$ & & $23(30.7)$ & $10(33.3)$ & \\
\hline \multicolumn{8}{|l|}{ Behavioral Variables } \\
\hline \multicolumn{8}{|l|}{ Smoking } \\
\hline Smoker & 10 & - & $2(10.0)$ & 0.30 & $4(5.3)$ & $4(12.9)$ & 0.17 \\
\hline Non- Smoker & 126 & $10(100.0)$ & $18(90.0)$ & & $71(94.7)$ & $27(87.1)$ & \\
\hline \multicolumn{8}{|l|}{ Alcohol Intake } \\
\hline Yes & 14 & - & $6(30.0)$ & 0.05 & $7(9.3)$ & $1(3.2)$ & 0.27 \\
\hline No & 122 & $10(100.0)$ & $14(70.0)$ & & $68(90.7)$ & $30(96.8)$ & \\
\hline \multicolumn{8}{|l|}{ Level of Physical Activity } \\
\hline High level & 11 & $2(20.0)$ & $4(20.0)$ & 0.84 & $5(6.7)$ & - & 0.31 \\
\hline Low level & 53 & $3(30.0)$ & $8(40.0)$ & & $30(40.0)$ & $12(38.7)$ & \\
\hline Moderate level & 72 & $5(50.0)$ & $8(40.0)$ & & $40(53.3)$ & $19(61.3)$ & \\
\hline \multicolumn{8}{|l|}{ Use of Medication } \\
\hline 3 or less & 85 & $7(33.3)$ & $3(33.3)$ & 1.0 & $54(70.1)$ & $21(72.4)$ & 0.81 \\
\hline 4 or less & 51 & $14(66.6)$ & $6(66.6)$ & & $23(29.8)$ & $8(27.5)$ & \\
\hline
\end{tabular}

MW: minimum wages; * Significance $\mathrm{p}<0.05$

\section{Methods}

This is an epidemiological cross-sectional study with 136 elderly individuals aged 60 years or more, both genders, assisted by Primary Health Care (PHC) in Bauru city, São Paulo State, Brazil, from June 2013 to July 2014.
Patients with osteoarthritis, with limited daily routine of movements, and those with limitation to respond and/or understand the questionnaire were excluded. After clarification about the study, individuals signed the Informed Consent Form (ICF). The study was approved by the Research Ethics Committee of the Medical School 
Table 2

Prevalence $(\%)$ of sarcopenia in individuals according to gender and age group. Brazil, 2013 (n = 136)

\begin{tabular}{lllll}
\hline & All & 60-69 year & 70-79 years & 80 or more \\
\hline Men & $66.7(\mathrm{n}=20)$ & $25.0(\mathrm{n}=5)$ & $60.0(\mathrm{n}=12)$ & $15.0(\mathrm{n}=3)$ \\
Women & $29.2(\mathrm{n}=31)$ & $38.7(\mathrm{n}=12)$ & $41.9(\mathrm{n}=13)$ & $19.3(\mathrm{n}=6)$ \\
\hline
\end{tabular}

Table 3

Nutritional status of individuals. Brazil, in $2013(\mathrm{n}=136)$

\begin{tabular}{lccc}
\hline & All (n=136) & Men (n=30) & Women (n=106) \\
\hline Overweight & $88(64.7)$ & $20(66.7)$ & $68(64.1)$ \\
Altered WC & $104(76.5)$ & $15(50.0)$ & $89(83.9)$ \\
Pre sarcopenia & $27(19.8)$ & $13(43.3)$ & $14(13.2)$ \\
Sarcopenia & $24(17.5)$ & $7(23.3)$ & $17(16.0)$ \\
\hline
\end{tabular}

WC: Waist Circumference

- UNESP - Botucatu and by the Research Ethics and Studies Committee of the Health Secretary of Bauru.

Socioeconomic and demographic variables such as gender, age, marital status, occupation, income (9), and education were assessed for all individuals along with information about tobacco dependence (10), alcohol consumption (11), physical activity (12), and medication use (13).

Anthropometric assessment was performed according to standard procedures. It was measured weight $(\mathrm{kg})$, height $(\mathrm{cm})$, waist circumference $(\mathrm{cm})$, and hip circumference $(\mathrm{cm})$. For body mass index (BMI) classification it was considered the reference LIPSCHITZ (1994), and for waist circumference (WC) classification it was considered the Brazilian Society of Hypertension (2005). Skeletal muscle mass (SMM) was obtained by Bioelectrical Impedance (BIA) (19) and calculated from the equation proposed by Janssen adjusted for gender and age (20). Absolute muscle mass ( $\mathrm{kg}$ ) was normalized to height (muscle mass (kg) / height (m2) and denominated Skeletal Muscle Mass Index (SMMI) $(19,21)$. Muscle strength was assessed by grip strength measured by the analogic hydraulic hand dynamometer (Jamarß) and according to standard procedures $(22,23$, 24).

Energy intake was assessed by two 24-hour dietary recall $(24 \mathrm{HR})$ with an average interval of 30 days, thus verifying the usual and recent dietary intake (17). The software Nutrition Data System for Research, version 2007, was used for dietary intake analysis (18).

The diagnosis of sarcopenia was established by EWGSOP criteria (4).

The prevalence of sarcopenia was estimated using 95\% confidence intervals. Descriptive statistics was performed (frequencies and percentages) for qualitative variables; and mean, median, standard deviation and decis for quantitative variables. Associations between sarcopenia and categorical variables were assessed by Chi-square test or Fisher's Exact Test. Univariate logistic regression was performed for obtaining the variables which correlate with the outcome, calculating the protective or risk factors correcting for possible confounding variables (gender, age, BMI, energy intake). The significance level was set at $5 \%$ for all tests.

\section{Results}

The characteristics of the individuals studied are shown in Table 1. The prevalence of sarcopenia in the study population was $37.5 \%, 66.6 \%$ for men and $29.2 \%$ women. The occurrence was higher in the group aged 70-79 years, for both genders (Table 2). Many of the individuals were overweight $(64.7 \%)$ and presented abnormal WC (76.5\%) (Table 3). Among individuals with sarcopenia, $50 \%$ of men and $29 \%$ of women were classified as overweight, $35 \%$ of men and $35 \%$ of women had WC classified as increased risk for cardiovascular diseases (CVD) and 35\% of men and $64 \%$ of women presented waist to hip ratio classified as increased risk. Muscle mass was significantly lower in patients with sarcopenia for both genders. The average hand grip was lower among individuals with sarcopenia, only statistically significant for women $(p=0.03)$. Most women with sarcopenia $(74.2 \%)$ showed loss of muscle strength (Table 4). Logistic regression analysis showed that retirement (OR: 2.116; CI: 1.282 to 3.491 ) and smoking (OR: 5.074; CI: 1.230 to 20.293) are risk factors for sarcopenia, even after adjustments for confounding variables. On the other hand, education represents a protective factor for sarcopenia (OR: 0.544; CI: 0.300 to 0.985), but when the model is adjusted for total energy intake the statistical significance lost its power (Table 5). 
Table 4

Anthropometric characteristics and muscle strength of the individuals according to gender and sarcopenia status. Brazil, $2013(\mathrm{n}=136)$

\begin{tabular}{|c|c|c|c|c|c|c|}
\hline & \multicolumn{3}{|c|}{ Men $(n=30)$} & \multicolumn{3}{|c|}{ Women $(n=106)$} \\
\hline & $\begin{array}{c}\text { No Sarcopenia } \\
(n=10)\end{array}$ & $\begin{array}{c}\text { Sarcopenia } \\
\quad(n=20)\end{array}$ & p-value* & $\begin{array}{c}\text { No Sarcopenia } \\
(n=75)\end{array}$ & $\begin{array}{c}\text { Sarcopenia } \\
(\mathbf{n}=31)\end{array}$ & p-value* \\
\hline Weight (kg) & $90.6 \pm 12.01$ & $72.6 \pm 9.61$ & $<0.001^{*}$ & $73.5 \pm 10.98$ & $58.5 \pm 8.70$ & $<0.001^{*}$ \\
\hline BMI $\left(\mathrm{kg} / \mathrm{m}^{2}\right)$ & $32.3 \pm 3.22$ & $26.8 \pm 3.76$ & $<0.001^{*}$ & $31.4 \pm 4.95$ & $24.8 \pm 3.42$ & $<0.001^{*}$ \\
\hline Underweight & - & $3(15.0)$ & $0.02 *$ & - & $6(19.4)$ & $<0.001^{*}$ \\
\hline Eutrophic & - & $7(35.0)$ & & $16(21.3)$ & $16(51.6)$ & \\
\hline Overweight & $10(100.0)$ & $10(50.0)$ & & $59(78.7)$ & $9(29.0)$ & \\
\hline $\mathrm{WC}(\mathrm{cm})$ & $113.0 \pm 9.81$ & $98.7 \pm 7.67$ & $<0.001^{*}$ & $103.4 \pm 10.95$ & $91.2 \pm 10.47$ & $<0.001^{*}$ \\
\hline Normal & $2(20.0)$ & $13(65.0)$ & & $6(8.0)$ & $13(69.0)$ & $<0.001^{*}$ \\
\hline Altered & $8(80.0)$ & $7(35.0)$ & & $69(92.0)$ & $7(35.0)$ & \\
\hline WHR & $1.06 \pm 0.09$ & $0.99 \pm 0.05$ & $0.01^{*}$ & $0.97 \pm 0.05$ & $0.94 \pm 0.07$ & $0.01^{*}$ \\
\hline Increased risk & $8(80.0)$ & $7(35.0)$ & $0.02 *$ & $69(92.0)$ & $20(64.5)$ & $<0.001$ \\
\hline Non-increased risk & $2(20.0)$ & $13(65.0)$ & & $6(8.0)$ & $11(35.5)$ & \\
\hline Handgrip (kg) & $36.0 \pm 6.80$ & $32.3 \pm 6.59$ & 0.16 & $21.2 \pm 4.66$ & $19.1 \pm 4.44$ & $0.03^{*}$ \\
\hline Good muscle strength & $7(70.0)$ & $11(55.0)$ & 0.42 & $39(52.0)$ & $8(25.8)$ & $0.01^{*}$ \\
\hline Loss of muscle strength & $3(30.0)$ & $9(45.0)$ & & $36(48.0)$ & $23(74.2)$ & \\
\hline SMMI $\left(\mathrm{kg} / \mathrm{m}^{2}\right)$ & $11.4 \pm 0.61$ & $9.4 \pm 0.84$ & $<0.001^{*}$ & $7.9 \pm 0.94$ & $6.1 \pm 0.40$ & $<0.001^{*}$ \\
\hline
\end{tabular}

BMI: Body Mass Index; WC: Waist Circumference; WHR: Waist to Hip ratio; SMMI: Skeletal Muscle Mass Index. Significance p <0.05

\section{Discussion}

The prevalence of sarcopenia in the present study was high and differed from previous studies $(19,6,8)$. In the study by JANSSEN et al. (2004), with muscle mass estimated by BIA, $53.1 \%$ of men and $21.9 \%$ of women were classified with sarcopenia. CHIEN et al. (2008) observed prevalence of sarcopenia in $18.6 \%$ of women and $23.6 \%$ of men (19). BEAUDART et al. (2014), found prevalence from $8.4 \%$ to $27.6 \%$ depending on the Diagnostic criterion used (using BIA, prevalence was $12.8 \%$ ) (8). A probable explanation for the variation in the prevalence rates of sarcopenia among studies could be related to the diversity of methods and diagnostic criteria to assess muscle mass, beyond ethnic differences in the populations studied. In Brazil there are few studies on sarcopenia prevalence rates. SILVA et al. (2013) (6) with data from the SABE [Saúde, Bem Estar e Envelhecimento] evaluated sarcopenia through the components: mass, muscle strength and performance, and found prevalence of $16.1 \%$ for women and $14.4 \%$ for men. The prevalence of sarcopenia in the population studied was higher in the group aged 70-79 years for both genders. BAUMGARTNER et al. (1998) (25) observed that sarcopenia prevalence increases with age, from $13 \%$ to $24 \%$ in elderly people below 80 years, and $60 \%$ for those over 80 years. SILVA et al. (2013) found increased sarcopenia frequency with aging $(\mathrm{p}<0.05)(6)$.

Our study showed that smoking increases five folds the chances of sarcopenia. SILVA et al. (2013) observed $15 \%$ increase of sarcopenia risk among elderly smokers (7). LEE et al. (2007) studied the association between sarcopenia and lifestyle in elderly people and found that cigarette smoking is associated with lower appendicular muscle mass. Smoking associated with aging can increase protein catabolism and muscle fatigue and reduce mass and muscle function (26).

The population of this study presented sedentary lifestyle. ROM et al. (2012) (27) found that retired individuals spend most of the time inactive. A sedentary lifestyle can be defined as the time a person remains sitting or lying and has been touted as one of the main risk factors for a number of diseases, including sarcopenia (28). The profile of the Brazilian elderly population is characterized by low income and low education, which leads most of the time to worsening health conditions (29). Most often, people with higher levels of education have health surveillance habits that include review of periodic health conditions and esthetic treatments (30).

This study presented some limitations. First, this was a cross-sectional study, which limits our ability to draw 
Table 5

Association of sociodemographic and lifestyle factors associated with the presence of sarcopenia in the subjects studied

\begin{tabular}{lccc}
\hline & Odds Ratio & $\begin{array}{c}\text { Confidence } \\
\text { Interval } \\
\mathbf{( 9 5 \% )}\end{array}$ & p-value* \\
\hline Retired & & & \\
Model 1 & 2.155 & $(1.312-3.537)$ & $0.002^{*}$ \\
Model 2 & 1.774 & $(0.949-3.319)$ & 0.07 \\
Model 3 & 2.116 & $(1.282-3.491)$ & 0.003 \\
Education & & & \\
Model 1 & 0.651 & $(0.396-1.069)$ & 0.08 \\
Model 2 & 0.544 & $(0.300-0.985)$ & $0.04^{*}$ \\
Model 3 & 0.666 & $(0.403-1.100)$ & 0.11 \\
Smoke Addiction & & & \\
Model 1 & 5.627 & $(1.408-22.492)$ & $0.01^{*}$ \\
Model 2 & 1.801 & $(0.351-9.252)$ & 0.48 \\
Model 3 & 5.074 & $(1.230-20.923)$ & $0.02^{*}$ \\
\hline Model 1: adjusted for age and gender; Model 2: Model 1+ BMI; Model 3: Model \\
2 + energy; Significance p $<0.05$
\end{tabular}

causal inferences. Second, it was restricted to apparently healthy people that were able to go to health care facilities. Third, most of the sample consisted of women. Fourth, participants were not asked about previous hospitalization in recent months, which may lead to reduced functional capacity.

In conclusion, our study found high prevalence of sarcopenia in elderly Brazilians, more prevalent among men and individuals above 70 years, along with a high prevalence of abdominal obesity, which may be an important causal factor for insulin resistance and type 2 diabetes susceptibility. Sarcopenia was also associated with behavioral (smoking) and demographic (retirement) variables.

\section{Conflict of Interest: The authors declare no conflict of interest.}

Ethics Standard: The study was approved by the Research Ethics Committee of the Medical School - UNESP - Botucatu and by the Research Ethics and Studies Committee of the Health Secretary of Bauru.

\section{References}

1. Cruz-Jentoft AJ, Baeyens JP, Bauer JM, Boirie Y, Cederholm T, Landi F, et al. Sarcopenia: European consensus on definition and diagnosis. Age Ageing. 2010;39:412-423.

2. Goodpastter BH, Park SW, Harris TB, Kritchevsky SB, Nevitt M, Schwartz $\mathrm{AV}$, et al. The loss of skeletal muscle strength, mass, and quality in older adults: the health, aging and body composition study. J Gerontol A Biol Sci Med Sci. 2006;61A:1059-1064.

3. Jones DP, Short KR, Campbell WW, Volpi E, Wolfe RR. Role of dietary protein in the sarcopenia of aging. Am J Clin Nutr. 2008;87:1562S-1566S.

4. Santilli V, Bernetti A, Mangone M, Paoloni M. Clinical definition of sarcopenia. Clin Cases Miner Bone Metab. 2014;11:177-180.

5. Bijlsma AY, Meskers CGM, Ling CHY, Narici M, Kurrle SE, Cameron ID, et al. Defining sarcopenia: the impact of different diagnostic criteria on the prevalence of sarcopenia in a large middle aged cohort. AGE 2013; 35:871881.
6. Silva TA, Duarte OYA, Santos FJL, Wong R, Lebrão ML. Prevalence and associated factors of sarcopenia among elderly in Brazil: findings from the SABE Study. J Nutr Health Aging 2013;18:284-290.

7. Newman AB, Kupelian V, Visser M, Simonsick E, Goodpaster B, Nevitt M, et al. Sarcopenia: Alternative definitions and associations with lower extremity function. J Am Geriatr Soc. 2003;51:1602-1609.

8. Beaudart, C, Reginster JY, Slomian J, Buckinx F, Dardenne N, Quabron A, et al. Estimation of sarcopenia prevalence using various assessment tools. Exp Gerontol 2014;61:31-37.

9. Instituto Brasileiro de Geografia e Estatística. Perfil dos idosos responsáveis por domicílios no Brasil (Internet). Rio de Janeiro: IBGE; 2000 [acesso 9 Jul 2012]. Disponível em: http:/ / www.ibge.gov.br.

10. Castro MG, Oliveira MS, Moraes JFD, Miguel AC, Araújo RB (2006) Qualidade de vida e gravidade da dependência de tabaco. Rev Psiquiatr Clín. 2006;34:61-67.

11. World Health Organization. Global status report on alcohol. WHO, Geneva, 2004;pp 88.

12. Craig CL, Marshall AL, Sjöstrom M, Bauman AE, Booth ML, Ainsworth BE, et al. International physical activity questionnaire: 12-country reliability and validity. Med Sci Sports Exerc. 2003;35:1381-1395.

13. Rollason V, Vogt N. Reduction of polypharmacy in the elderly. A systematic review of the role of the pharmacist. Drugs Aging. 2003;20:817-832.

14. Oliveira EP, Camargo KF, Castanho GKF, Nicola M, MacLellan KCP, Burini RC. A variedade da dieta é fator protetor para a pressão arterial sistólica elevada. Arq Bras Cardiol. 2012;98:338-43.

15. Sociedade Brasileira de Hipertensão. Sociedade Brasileira de Cardiologia. Sociedade Brasileira de Endocrinologia e Metabologia. Sociedade Brasileira de Diabetes. Associação Brasileira para Estudos da Obesidade. I Diretriz Brasileira de Diagnóstico e Tratamento da Síndrome Metabólica. Arq Bras Cardiol. 2005;84:1-28.

16. Lipschitz DA. Screening for nutritional status in the elderly. Prim Care 1994;21:55-67.

17. Fisberg RM, Martini LA, Slater B. Métodos de inquéritos alimentares. In: Fisberg RM, Slater B, Marchioni DML, Martini LA. Inquéritos alimentares: métodos e bases científicos, Manole, São Paulo, 2005;pp. 1-31.

18. Schakel SF, Buzzard IM, Gebhardt SE. Procedures for estimating nutrient values for food composition databases. J Food Comp and Anal. 1997;10:102114.

19. Chien MY, Huang TY, Wu YT. Prevalence of sarcopenia estimated using a bioelectrical impedance analysis prediction equation in community-dwelling elderly people in Taiwan. J Am Geriatr Soc 2008;56:1710-1715.

20. Janssen I, Heymsfield SB, Baumgartner RN, Ross R. Estimation of skeletal muscle mass by bioelectrical impedance analysis. J Appl Physiol. 2000;89:465471.

21. Janssen I, Baumgartner R, Ross R, Rosenberg IH, Roubenoff R. Skeletal muscle cutpoints associated with elevated physical disability risk in older men and women. Am J Epidemiol. 2004;159:413-421.

22. Dias JA, Ovando AC, Külkamp W, Borges NG. Força de preensão palmar: métodos de avaliação e fatores que influenciam a medida. Rev Bras Cineantropom Desempenho Hum. 2010;12:209-216.

23. Abizanda P, Navarro JL, García-Tomás MI, López-Jiménez E, MartínezSánchez E, Paterna G. Validity and usefulness of hand-held dynamometry for measuring muscle strength in community-dwelling older persons. Arq Gerontol Geriatr 2012;54:21-27.

25. Sallinen J, Stenholm S, Rantanen T, Heliövaara M, Sainio P, Koskinen S. Hand-Grip strength cut-points to screen older persons at risk for mobility limitation. J Am Geriatr. 2010;58:1721-1726.

25. Baumgartner RN, Koelher KM, Galagher D, Romero L, Heymsfield SB, Ross RR, et al. Epidemiology of sarcopenia among the elderly in New Mexico. Am J Epidemiol 1998;147:755-763.

27. Lee JS, Auyeung TW, Kwok T, Lau EM, Leung PC, Woo J. Associated factors and health impact of sarcopenia in older Chinese men and women: a crosssectional study. Gerontology. 2007;53:404-410.

27. Rom O, Kaisari S, Aizenbud D, Reznich AZ. Lifestyle and Sarcopenia - Etiology, Prevention and Treatment. Rambam Maimonides Med J. 2012;3:e0024, doi: 10.5041/RMMJ.10091.

28. Chastin SFM, Ferriolli E, Stephens NA, Fearon KCH, Greig C. Relationship between sedentary behaviour, physical activity, muscle quality and body composition in healthy older adults. Age Ageing. 2012;41:111-114.

29. Rosa, N. et al. Interleukin-6 plasma leves and socioeconomic status in Brazilian elderly community-dwelling women. Arch Gerontol Geriatric., Amsterdam, v.53, p.196-99, Nov.2011.

30. Pinheiro RS, Travassos C. Estudo da desigualdade na utilização de serviços de saúde por idosos em três regiões da cidade do Rio de Janeiro. Cad Saúde Pública. 1999;15:487-496. 